\title{
IMPACT OF CONTROLLING SYSTEMS ON DIRECT COSTS OF CONSTRUCTION PROJECTS
}

\author{
Tomáš Mandičák \\ Technical University of Košice, Faculty of Civil Engineering, Department of Construction Technology and \\ Management, Vysokoškolska 4, 04200 Košice, tomas.mandicak@tuke.sk \\ Annamária Rakošiová \\ Technical University of Košice \\ Technical University of Košice, Faculty of Manufacturing Technologies, Department of Manufacturing Management, \\ Bayerova 1, 08001 Prešov, annamaria.rakosiova@tuke.sk
}

Keywords: exploitation of economic controlling systems, direct costs, construction projects

Abstract: Cost planning and cost management is one of the condition for successfully manage to construction project. Efforts to reduce direct costs is a priority for reaching and realization of the objectives. Implementation of controlling is one way to achieve these goals. Currently, there are several ways to automate and systematized these activities. One of them are Controlling systems. Several studies indicate that their use have a lot of benefits. Article discusses the issue of exploitation level of Controlling systems for cost management and reduce direct costs of construction projects. The main objective of this article is to confirm the hypothesis that verify to the following statement: Enterprise size has an impact on the use of Controlling systems for direct cost planning in construction projects and exploitation of Controlling systems have a significant impact on reducing the direct costs of construction projects in difference to the size of construction enterprises.

\section{Introduction and problem statement}

Recent years are characterized by dynamic progresses exploitation and implementation of information and communication technologies [1]. The need for data and information in the knowledge society is growing very quickly [2]. The competitive environment is forcing companies to make quick and effective decisions on a daily basis [3]. With increasing amounts of data and information, there is an even more important selection and the need to use relevant data to support decision making in the management and coordination of companies and projects in each area [4]. The use of advanced technologies to support management in many companies is a priority and one of the main steps and procedures to successfully manage companies and projects [5]. Interconnectivity the various technologies and systems and their multifunctionality avoid talking about this group of technologies only at intervals of information systems [6]. These in many cases are separated.

Information and communication technologies (ICTs) (Communiaction-Information Technologies - ICTs) represent a complex hardware and software. This includes communication technologies that enable data processing [7]. ICT is a broad term and includes a number of technologies [8]. The economic system is relatively broad term. But the opposite of ICT is only focused on the economic agenda. The economic system is a type of system, whose main functionality is the economic agenda of the business or project [9]. In many cases it includes accounting software. Building business success depends on many factors [10]. Level managing all operations and effects are ultimately reflected in the amount of costs and prices realized performance [11], [12]. That is the upshot - profit. One of the goals of any entrepreneur is to make a profit. Strategic controlling identify future opportunities and risks of routing each company or business [13]. This is a basic function of strategic controlling. It follows another important task - to manage and control all implemented measures to move towards implementation of the goals of the corporate strategy [14]. Involvement at this stage The operational controlling. It is timely to recognize deviations from the basic direction by properly elected executive - operational tools [15]. Strategic and operational controlling jointly created two functional units that are connected and influence each other [16].

According to E. Mayer [17] controlling is a management process focuses on operating result, which is realized by means of planning, monitoring and verification. Controlling is based on the harmonization of the objectives set out by managers and staff and objectives set out by company. Controlling has a major role to ensure long-term company's survival and stable employment. These tasks require coordination management system that can be achieved by establishing an appropriate organizational structure and integration objectives with planning and information systems.

Controlling systems are information systems that perform the functions exercised by the controlling in company. They are supporting tools that make automation of planning, management and control activities in the company. In the context of controlling it is important to 
IMPACT OF CONTROLLING SYSTEMS ON DIRECT COSTS OF CONSTRUCTION PROJECTS

Tomáš Mandičák; Annamária Rakošiová

plan costs for the selected activity. The cost of the construction project can be divided according to the different phases. The very process of construction cost management project includes the following [18]:

- cost planning and economic feasibility of the project at the planning stage,

- monitoring and forecast of efficiency and utilization of financial sources,

- proposal for measures to deal with deviating development (cost and time) at the realization stage of construction project,

- assessment of the real effectiveness of the construction project at realization stage of construction project.

Control of costs and estimated costs of the construction project is to specify the cost of the necessary procedures, which are implemented throughout the lifecycle of a construction project. Costs of construction projects can be classified according to several different criteria. In terms of cost calculation formula is broken down [12]:

- direct costs - this includes:

- direct material,

- direct wages,

- costs for machinery and equipment,

- subcontracting,

- manufacturing overhead,

- administrative expenses.

This breakdown is also important in terms of research, the results of which are also interpreted in this paper.

\section{Methodology}

\subsection{Research objectives and methods}

In the article they were used empirical methods of investigation and research. Within the empirical methods were used on a larger scale observation, questionnaire survey and interviews with business. From theoretical methods they were most used method of abstraction, analysis and synthesis, and methods of induction and deduction. The methodological framework during the research:

1. Determine the subject and scope of research.

2. Selection of the research group and content.

3. Processing questionnaires for data collection.

4. Data collection.

5. Evaluating data based on the detection levels of importance factors examined.

6. Verify the statistical significance of the results based on the Kruskal-Wallis test.

\subsection{Data collection methods}

The questionnaire survey appeared to be the fastest and most effective way of obtaining the necessary information for research purposes. The questionnaire was designed and distributed in electronic form. For preparation of the questionnaire was used online platform forms which permit the questionnaire in electronic form, accessible to him of the selected target group respondents based on the destination address where the questionnaire is placed. This form ensures that the questionnaire can only see us respondent and no adverse unprofessional person.

The survey sample was approached by e-mail with the request to participate in the research. Total were interviewed 1276 of respondents (participants of construction projects). It participated in the questionnaire survey 125 respondents, but only 55 companies completed the entire questionnaire to use in our research. It represents a return of $4.31 \%$. Given the scale of the areas examined in the questionnaire survey, it is possible to return to the level of $4.31 \%$ which is considered as good. Complete the questionnaire contained approximately 2,500 research questions, broken down into research areas of the same nature and its actual completion took approximately 50 minutes.

\subsection{Research sample}

The questionnaire survey featured data collection using the online questionnaire. Link to the online questionnaire was sended to respondends in electronic form with an explanatory covering letter.

Main characteristics of research subjects in terms of the size of the company we can see thereunder. Participated in the survey and a questionnaire completed by $34,55 \%$ of micro-companies, $30,91 \%$ of small companies, $21,82 \%$ of medium-sized companies, what constitutes $35.71 \%$ of the research sample and $12,73 \%$ of large enterprises (Figure 1).

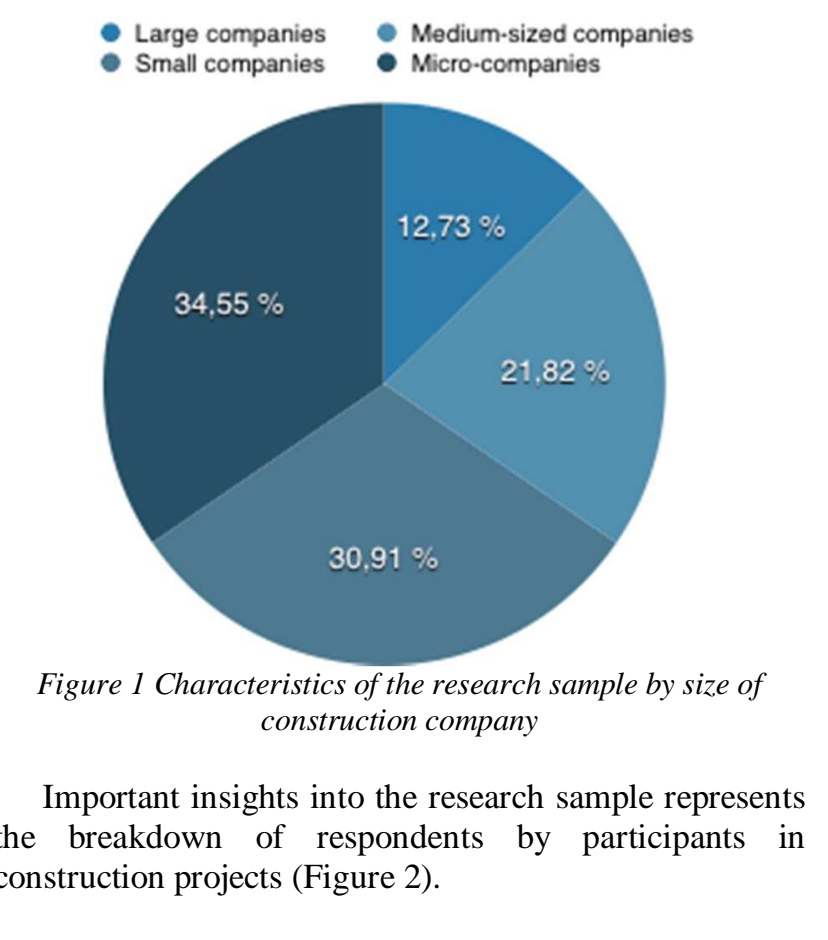


IMPACT OF CONTROLLING SYSTEMS ON DIRECT COSTS OF CONSTRUCTION PROJECTS

Tomáš Mandičák; Annamária Rakošiová

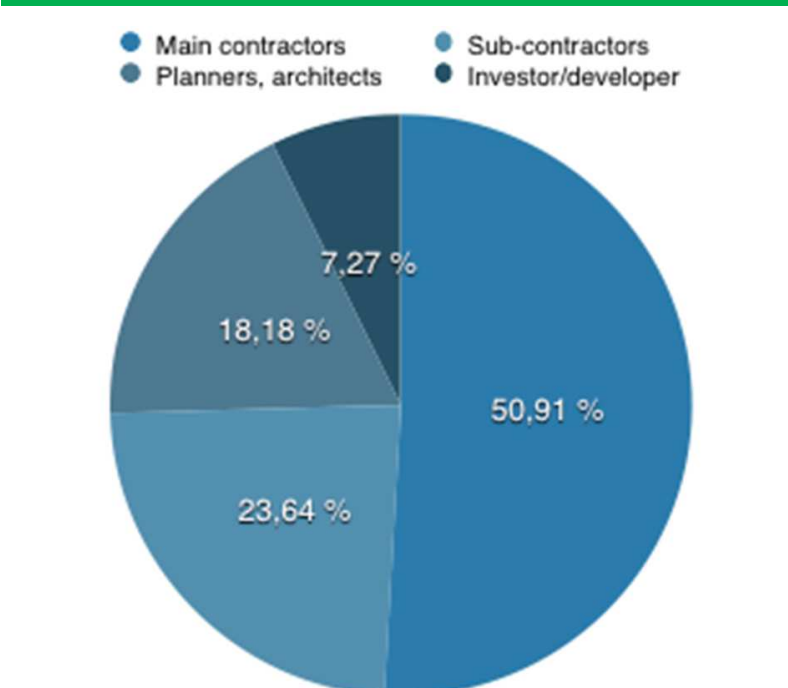

Figure 2 Characteristics of the research sample by participant of construction project

\subsection{Data processing method}

The obtained data were evaluated based on several statistical methods through software MS Excel and statistics. Results of the research were based on a descriptive and inductive statistics.

Evaluation of data was based on the use of so-called exploitation rate, respectively impact rate. Arithmetic average of the selected area was determined by the average value. The range was fixed by Likert scale (1 to $5)$. Using the measures have been made arithmetic mean of the values for the selected area under consideration.

Statistical significance was tested by Kruskal - Wallis test at the significance level $\alpha=0.05$. Kruskal - Wallis test (Kruskal - Wallis ANOVA) is a direct generalization of the Wilcoxon two-sample test case for independent samples. Kruskal - Wallisow test is similar to the nonparametric one-way analysis of variance [19].

Kruskal - Wallisow assay is based on the ranks. This is a non-parametric method for testing. Research samples were tested, whether they were of equal distribution. It is used to compare two or more samples dependent on the same or different size [20], [21].

\subsection{Hypotheses}

Basic scientific hypotheses in these areas have been set as follows:

$\mathrm{H}_{0}$ : Enterprise size has an impact on the use of Controlling systems for direct cost planning in construction projects.

$\mathrm{H}_{1}$ : Enterprise size has not an impact on the use of Controlling systems for direct cost planning in construction projects.

$\mathrm{H} 2_{0}$ : Exploitation of Controlling systems has a significant impact on reducing the direct costs of construction projects in difference to the size of construction enterprises.

$\mathrm{H} 2_{1}$ : Exploitation of Controlling systems has not a significant impact on reducing the direct costs of construction projects in difference to the size of construction enterprises.

\subsection{Objectives of research}

The main objective of the research was to verify that the exploitation of controlling systems has a significant impact on reducing the direct costs of construction projects in difference to the size of construction companies. It comes with the knowledge that the enterprise size has an impact on the exploitation of Controlling systems for direct cost planning and construction projects.

\section{Results}

The aim of this survey was to understand and verify the effect of size on the use of Controlling systems. Endpoints are compared between companies. It is expected that large companies behave differently in ICT investment as small and medium sized companies (SMEs). The same is true for investing in a specific instrument for the do a controlling (includes direct cost planning). The results of the use can be seen in figure 3 .

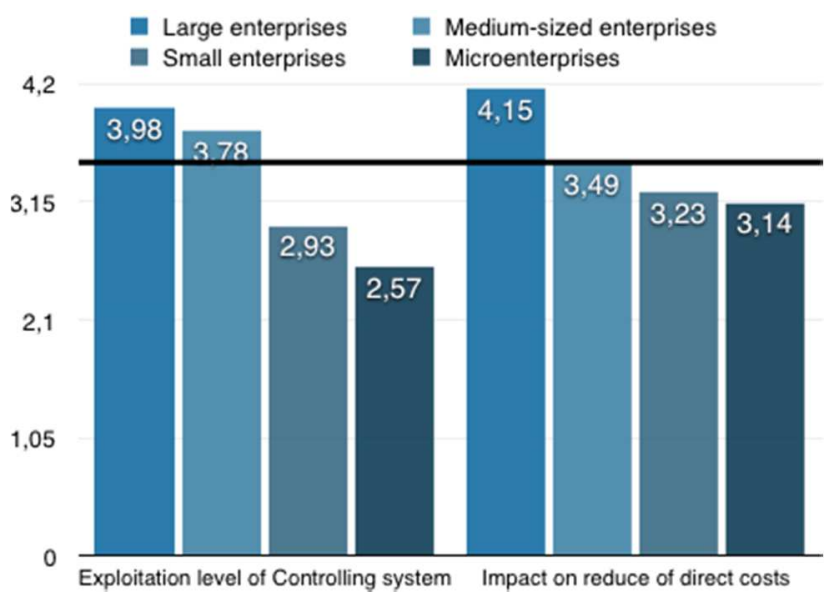

Figure 3 Exploitation level of Controlling systems for cost management and impact to reduce of direct costs

Large construction enterprises use Controlling systems for the purpose of direct costs planning in construction projects in the rate 3,98 . This is a very high impact. Medium-sized construction enterprises achieved utilization rate 3,78 . It is equally high.

Conversely, small enterprises achieved utilization rate of only 2,57 and micro-enterprises only 2,93. This is a very low value. This means that small enterprises have been a minor use tool a Controlling System. This probably reflects a lot of things. The survey reveals that small businesses really do not have enough funds to 
IMPACT OF CONTROLLING SYSTEMS ON DIRECT COSTS OF CONSTRUCTION PROJECTS

Tomáš Mandičák; Annamária Rakošiová

invest in progressive systems. On the other hand, many companies that either do not see the advantage of a lot of things out manually.

Table 1 Kruskal-Wallis test for examing of the statistical significance

Kruskal-Wallis ANOVA based on ranking, Variable - size of construction enterprise $\mathrm{p}=0,0347$

\begin{tabular}{lc|c|c|}
\hline & Code & $\begin{array}{c}\text { Number } \\
\text { of valid } \\
\text { responses }\end{array}$ & $\begin{array}{c}\text { Exploitation } \\
\text { level }\end{array}$ \\
$\begin{array}{l}\text { Large enterprises } \\
\text { Medium-sized }\end{array}$ & 1 & 7 & 3,98 \\
enterprises & 2 & 12 & 3,78 \\
Small enterprises & 3 & 17 & 2,93 \\
Microenterprises & 4 & 19 & 2,57 \\
\hline
\end{tabular}

Source: own processing - the output of STATISTICA 12

Table 1 describes the Kruskal - Wallis test for examining the statistical significance of construction enterprises size impact on the exploitation of Controlling systems. Controlling systems amounted $p=0.0347$. From that it follows that statistical significance was confirmed a confidence level of $\alpha=0.05$ and we accept the hypothesis $\mathrm{H} 1_{0}$, thus: Enterprise size has an impact on the use of Controlling systems for direct cost planning in construction projects.

Table 2 Kruskal-Wallis test for examing of the statistical significance

\begin{tabular}{lc|c|c}
\hline & \multicolumn{3}{l}{$\begin{array}{l}\text { Kruskal-Wallis ANOVA based on } \\
\text { ranking, Variable - impact on } \\
\text { reducing the direct costs of } \\
\text { construction projects in difference } \\
\text { to the size of construction } \\
\text { enterprises. p=0,0216 }\end{array}$} \\
\hline $\begin{array}{l}\text { Code } \\
\text { Marge enterprises }\end{array}$ & $\begin{array}{c}\text { Number } \\
\text { of valid } \\
\text { Medium-sized }\end{array}$ & $\begin{array}{c}\text { Exploitation } \\
\text { level }\end{array}$ \\
$\begin{array}{l}\text { enterprises } \\
\text { Small enterprises } \\
\text { Microenterprises }\end{array}$ & 2 & 7 & 4,15 \\
\hline
\end{tabular}

Source: own processing - the output of STATISTICA 12

A similar situation occurs also when examining the exploitation of Controlling system impact on reducing direct costs of construction projects. The degree of Controlling system exploitation impact to reduce direct costs of construction projects is 4,15 for large construction enterprises. The degree of Controlling system exploitation impact to reduce direct costs of construction projects is 3,49 for the medium-sized construction enterprises. The degree of Controlling system exploitation impact to reduce direct costs of construction projects is only 3,13 for small enterprises. Influence is clearly demonstrated for large construction companies (Figure 3).

Table 2 describes the Kruskal - Wallis test for examining the statistical significance of exploitation of Controlling system impact on reducing direct costs of construction projects. It amounted $\mathrm{p}=0.0216$. From that it follows that statistical significance was confirmed a confidence level of $\alpha=0.05$ and we accept the hypothesis $\mathrm{H} 2_{0}$, thus: Exploitation of Controlling systems has a significant impact on reducing the direct costs of construction projects in difference to the size of construction enterprises.

\section{Conclusions}

Several surveys have shown that the use of ICT is a very effective tool to reduce costs in the chosen area. Our survey was more specific. Subject of research was the impact of exploitation of controlling systems to reduce the direct costs of construction projects. It was also researched the rate of exploitation of Controlling system tools. Within the framework of the research are expected positive impact of exploitation of Controlling Systems. These expectations have been included in the determination of basic research hypotheses. Both hypotheses were confirmed. That means, enterprise size has an impact on the use of Controlling systems for direct cost planning in construction projects and exploitation of Controlling systems has a significant impact on reducing the direct costs of construction projects in difference to the size of construction enterprises.

\section{Acknowledgement}

"The paper presents partial results of the research project VEGA No. 1/0562/14 ,The impact of Business Intelligence tools on corporate performance“.

"The paper presented a partial research result of project "Identification of key competencies of university students for the needs of knowledge society development in Slovakia", which is supported by the Ministry of Education, Science, Research and Sport of the Slovak Republic in supplying incentives for research and development from the state budget in accordance with Act no. 185/2009 Z.

"The paper presented a partial research result of project VEGA - 1/0677/14 "Research of construction efficiency improvement through MMC technologies".

\section{References}

[1] KRŠÁK, B., TOBISOVÁ, A., SEHNÁLKOVÁ, M.: Information technologies and their using during firm's 
IMPACT OF CONTROLLING SYSTEMS ON DIRECT COSTS OF CONSTRUCTION PROJECTS

Tomáš Mandičák; Annamária Rakošiová

financial health modelling. Transactions of the Universities of Košice, Vol. 4., pp. 35-40, 2011.

[2] DUGAS, J, MESÁROŠ, P., FERENCZ, V., ČARNICKÝ, Š.: Business Communication Systems, 1. vyd. Brussels: Euroscientia vzw, 167 p., 2015.

[3] ONDREJKA, R., MORAVČÍKOVÁ, L.: Mathematical modelling within the road safety management, Acta Tecnología, Vol. 1., No. 2, pp. 58., 2015.

[4] KRŠÁK, B., TOBISOVÁ, A., SEHNÁlKOVÁ, M.: Education in information technology as a tool for tourism development. In: Procedia - Social and Behavioral Sciences 116 : WCES 2013, 5th World Conference on Educational Science, Holandsko : Elsevier, 2014, pp. 1096-1100, [Online], Available: http://ac.els-cdn.com/S1877042814003681/1-s2.0S1877042814003681-main.pdf?_tid=4ff845f8-adb411e3-9f [20 Jun 2014], 2014.

[5] JANČÍK, M., PANDA, A., BEHÚN, M.: Production management, Studia i materialy, Vol. 31, No. 1, p. 5759, 2012.

[6] ČARNICKÝ, Š.: Manažérske informačné systémy podnikov, Bratislava: Ekonóm, 2004. (Original in Slovak)

[7] GÁlA, L. et al. Podniková informatika - 2, prepracované a aktualizované vydanie, Praha, Grada Publishing, a.s., p. 496, 2009. (Original in Czech)

[8] MANDIČÁK, T., MESÁROŠ, P., RAKOŠIOVÁ, AM.: Exploitation of economic information systems for cost management in Slovak construction companies, Acta Tecnología, Vol. 2., No. 1, pp. 1-5, 2016.

[9] MESÁROŠ, P., MESÁROŠOVÁ, A., FERRERHernandez, M.: Augmented reality as a part of integrated designing and modeling the parameters of reconstruction projects, Integrated approaches to the design and management of buildings reconstruction. Brussels: EuroScienta vZw, p. 25-35, 2014.

[10] LESNIAK, A., PLEBANKIEWICZ, E., ZIMA, K.: Design and build procurement system - Contractor selection, Archives of Civil Engineering, Vol. 58, No. 4, pp. 463-476, 2012.

[11] MESÁROŠ, P., MESÁROŠOVÁ, A., FERRERHERNANDEZ, M.: Economics and Management of Construction Projects Financing of construction projects and cost management: Pricing of construction projects and cost management. Integrated design and management of construction projects. - Košice: TU, p 114-125, 2013.

[12] DIMA, Ioan, C., MODRÁK, V.: The Management of Basic Production Function. Industrial Production Management in Flexible Manufacturing Systems. Hershey: IGI Global, p. 110 - 175, 2013.

[13] MESÁROŠ, F., MESÁROŠ, P., SELÍN, J.: Controlling nákladov na stavebné procesy, 2. dopl, vyd. - Košice: Výskumný ústav stavebnej informatiky, p. 250, 2013. (Original in SLovak)
[14] ZIMA, K.: The use of fuzzy case-based reasoning in estimating costs in the early phase of the construction project, AIP Conference Proceedings. 2015, Vol. $1648,2015$.

[15] SELÍN, J.: Možnosti optimalizácie stavebných dodávok, Inovatívny prístup $\mathrm{k}$ modelovaniu inteligentných konštrukčných prvkov v stavebníctve,: zborník vedeckých prác, Košice, VÚSI, p. 137-144, 2009. (Priginal in Slovak)

[16] RADZISZEWSKA-ZIELINA, E.: Fuzzy control of partnering relations of a construction enterprise, Journal of Civil Engineering and Management, Vol. 17, No. 1, pp. 5-15, 2011.

[17] MAIER, R.: Knowledge management systems (information and communication technologies for knowledge management), Berlin: Springer, 2004.

[18] PETRÁKOVÁ, Z. et al.: Využitie projektového riadenia $\mathrm{V}$ stavebníctve a investičnej výstavbe, Vydavatel'stvo STU v Bratislave, second edition, 2003. (Original in Slovak)

[19] MARKECHOVÁ, D., TIRPÁKOVÁ, A., STEHLÍKOVÁ, B.: Základy štatistiky pre pedagógov, UKF Nitra, 2011. (Original in Slovak)

[20] CORDER, GREGORY W., FOREMAN, DALE I.: Nonparametric Statistics for Non-Statisticians, Hoboken: John Wiley \& Sons. pp. 99-105, 2009.

[21] KRUSKAL, W. H., WALLIS, W. A.: Use of ranks in one-criterion variance analysis, Journal of the American Statistical Association, Vol. 47, No. 260, pp. 583-621, 1952.

\section{Review process}

Single-blind peer reviewed process by two reviewers. 